\title{
Bourdieu's non-material forms of capital: implications for start-up policy
}

\begin{abstract}
The role of Bourdieu's non-material forms of capital (cultural, social and symbolic) in the entrepreneurial process has received little dedicated research attention. Similarly, the link between occupationally distinct entrepreneurship and accumulation of non-material capitals is understudied. Addressing this, we examine the non-material capitals of different nascent entrepreneurs by occupational classification who participated on two enterprise-training programmes funded by the 1997-2010 Labour Government; each with considerably different foci. Findings demonstrate that professional and higher technician entrepreneurs possess valuable non-material capitals, in contrast to non-professional entrepreneurs. Against the backdrop of recent business enterprise policy, findings suggest that policy-makers should prioritise focused support that nurtures the valuable, productive non-material capitals of professional and higher technician entrepreneurs. Furthermore, initiatives should be tailored to improve the less distinguished non-material capitals of non-professional entrepreneurs.
\end{abstract}

\section{Introduction}

Entrepreneurship has long been recognised as an economic driver (Audretsch, 2007; Drucker, 1985; Schumpeter, 1934). Like most governments, successive administrators in England have sought to implement policies which encourage and support new firms (Atherton, 2006; Bennett, 2008, 2014; Blackburn and Ram, 2006; Down, 2012; Greene et al, 2008; Huggins and Williams, 2009, 2011; Robson et al, 2009; Storey and Greene, 2010; Williams, 2013). The business enterprise policies of all recent Governments: (Labour, 2007 - 2010; Coalition, 2010 - 2015; and current Conservative administration, 2015 -) support both new innovative firms and start-ups by the unemployed and in deprived areas with high unemployment. ${ }^{1}$ But there has been a significant policy creep towards prioritising high potential and 'innovative' new businesses 'with the ambition to grow' (BIS, 2013:8). 'Mainstream' entrepreneurial startups typically reflects tradespeople and unskilled/semi-skilled work (DWP, 2013; UKCES, 2011), while high-potential and innovation-intensive new firms represent technical, scientific and professional activities (Shane, 2009). Despite support for start-ups in England, policymakers recognise the need to better 'understand the characteristics of our small and medium sized businesses' (BIS, 2013:5). Furthermore, policymakers consider raising an awareness of the 'intangible assets' deemed important for entrepreneurial businesses to be a priority (BIS, 2011:88-89). According to Bourdieu (1986), non-material capitals better reflect intangibles, because they represent a class of practices that are socially recognised and convertible. Bebbington (1999:2022) notes that various nonmaterial capitals facilitate 'the capability to be and act'. Accepting this, there is a need to

\footnotetext{
${ }^{1}$ Relevant policy documents include: BIS, 2011, 2013, 2014, 2015; DTI, 2000; DWP, 2013; House of Commons Cm 8980, 2014; House of Commons Briefing 7363, 2015; House of Commons Cm 9039, 2015; House of Commons SN/EP/05878, 2015; House of Commons SN/EP/5651, 2015; Lord Young Feb 2015; ODPM, 2004; PRO INNO, 2008; UKCES, 2011; White Paper, 2010.
} 
sensitise policymakers about the importance of intangibles, specifically non-material capitals, in terms of different entrepreneurs by occupational classification.

That the process of creating sustainable and productive new ventures is determined by both tangible and intangible resources is not a new proposition (Drucker, 1985; Eckhardt and Shane, 2003). It is only more recently that researchers have sought to apply and understand Bourdieu's (1986) conception of non-material forms of capital (cultural, social and symbolic) in the entrepreneurial process (DeClercq and Voronov, 2009a, 2009b; Drakopoulou Dodd et al, 2014; Spigel, 2013; Tatli et al, 2014). The positive influence of social capital on entrepreneurial performance has become quickly established within the entrepreneurship literature and is now recognised as relevant by policy-makers (Anderson and Jack, 2002; Davidsson and Honig, 2003; EC, 2013; OECD, 2014; Ram et al, 2008; Westlund and Bolton, 2003). However, empirical studies of cultural and symbolic capital during venture creation are scant (Drakopoulou Dodd, 2014; KaratasOzkan, 2011; Lee, 2011; Light and Dana, 2013; Scott, 2012; Shaw et al, 2008, 2009, 2013; Vershinina et al, 2011).

Bourdieu (1993:64) also maintained that 'job definitions', 'posts' and 'different positions...their modesty or daring... [their] disinterestedness or thirst for profit' helps explain 'divisions' in the field of economic production, created as a consequence of disparities in the amounts and forms of non-material capitals available to actors (also see Svendsen and Sorensen, 2007). Building on this, DeClercq and Voronov (2009a:411) posit that entrepreneurial capital accumulation must be considered 'as an activity located at the intersection of entrepreneurs' lives and professional trajectories'. Indeed, few studies address occupationally different self-employment and information for public policymakers 'is piecemeal' (UKCES, 2011:39). For Zahra and Wright (2011:77), 'different entrepreneurs may apply different logics and construct their causal chains differently...these differences could illuminate the micro-foundations of entrepreneurial activity'. Focusing on different entrepreneurs by occupation and their non-material capitals may provide insights into why some entrepreneurs are more growth oriented than others (Wright and Stigliani, 2013).

Responding to these gaps, we examine the non-material capitals (cultural, social and symbolic) of different nascent entrepreneurs by occupational classification. That is, the occupational classification of different self-employment. We address the challenge that entrepreneurship scholars should 'examine the role of discourse about entrepreneurship in contemporary capitalist societies...and government agendas' (DeClercq and Voronov, 2009a:412) and that 'intangible assets... are not thoroughly understood' and 'overlooked in policy discussions' (OECD, 2014:58). Thus, we targeted entrepreneurs participating on two nationally important and dissimilar enterprise training programmes (New Entrepreneurship Scholarship NES, Science and Enterprise Challenge SEC) funded by the 1997-2010 Labour Government. The NES promoted start-ups in multiply deprived areas to tackle the lack of employment opportunities (DfES, 2003; Rouse and Jayawarna, 2006, 2011; UKCES, 2011) and primarily supported nonprofessional or tradesman self-employment (DWP, 2013; Jayawarna et al, 2007; UKCES, 2011). The SEC trained scientific and technical entrepreneurs (Kothari and Handscombe, 2007; SQW, 2005) and can be regarded as a forerunner to the recent focused support to 
promote high potential new businesses (BIS, 2011, 2014; House of Commons Cm 9039, 2015). The SEC encouraged technical and professional self-employment (SQW, 2005).

Next, we discuss business enterprise policy and forms of capital before considering self-employment occupations. Then we describe our research methods, in particular, core qualitative data and supplemental quantitative data. We continue by presenting and discussing findings, and providing policy recommendations.

\section{Entrepreneurship and Policy}

In the UK, public policymakers support various types of entrepreneurship and enterprising behaviour (Blackburn and Smallbone, 2011; Brooksbank, 2008; Greene, 2009; Hannon, 2003; Henry et al, 2003; Henry, 2010; Keogh, 2002; Mason, 2009; Pickernell et al, 2011, 2015; Ritchie, 2006; Taylor and Plummer, 2003). Consequently, policy interventions reflect tailored and bespoke support for: women-owned businesses (Marlow et al, 2008; Rouse and Kitching, 2006; Wilson et al, 2004); disabled people (Kitching, 2006); ethnic minorities and refugees (Deakins et al, 2003; Lyon et al, 2007; Ram and Smallbone, 2002; Ram and Jones, 2008; Ram et al, 2012); students and graduates (Pickernell et al, 2011); and rural enterprises (Anderson et al, 2005; Lee and Cowling, 2015; Smallbone et al, 2003; Sutherland and Burton, 2011).

At the same time, business enterprise policy represents interventions to stimulate both the economic impacts of high-potential start-ups and social mobility benefits of selfemployment (Huggins and Williams, 2009, 2011; Storey and Greene, 2010; Williams, 2013). The 1997-2010 Labour government addressed social exclusion and promoted selfemployment opportunities to the unemployed and those residing in deprived areas (Blackburn and Ram, 2006; Jones and Jayawarna, 2010; Lee et al, 2011; Rouse and Jayawarna, 2006, 2011; Slack, 2005; Taylor et al, 2004; Williams and Williams, 2011; Williams and Huggins, 2013). Through its 'Science and Innovation Policy for the $21^{\text {st }}$ Century', this Government simultaneously sought to increase the rates of value added and knowledge-driven entrepreneurship (Delcloque and Auckland, 2004; DTI, 2000; Huggins and Williams, 2009; Kothari and Handscombe, 2007; SQW, 2005). However, the 20102015 Coalition publicly declared a preference for prioritising high potential entrepreneurship through 'focused' investment (BIS, 2011, 2013, 2014, 2015; House of Commons Cm 8980, 2014; White Paper, 2010) while ensuring enterprise support keeps in mind interventions for the unemployed and disadvantaged (BIS, 2015; DWP, 2013; House of Commons Cm 9039, 2015; White Paper, 2010). In the new 'Enterprise Bill', the current Conservative Government suggest further measures to enable striving and growth oriented small businesses (BIS/15/498, 2015). Moreover, they will ensure adequate opportunities for the unemployed and generic start-ups (GOV UK Press release, 2015; House of Commons SN/EP/05878, 2015).

This recent policy shift converges with Shane's (2009:145) assertion that public policymakers should prioritise support interventions for 'the subset of businesses with 
growth potential'. Furthermore, he stresses the 'need to recognize that all entrepreneurs are not created equal' (Shane, 2009:146). ${ }^{2}$

\footnotetext{
${ }^{2}$ Furthering Shane's (2009) argument, high potential start-ups represent technical and knowledge-driven activities, high innovation intensity, productivity growth, knowledge transfer, equity investment, IP and commercialisation (BIS, 2011, 2014; Brown and Mawson, 2015; PRO INNO, 2008). High potential new firms can be scientific and technology-based, but also in various service sectors (Mason and Brown, 2013).
} 


\section{Entrepreneurship and Forms of Capital}

Despite significant support for the view that entrepreneurship and new venture creation is predicated on access to a mix of tangible and intangible resources (Eckhardt and Shane, 2003), entrepreneurship researchers have only recently adopted a wider perspective on capital (DeClercq and Voronov, 2009a, 2009b; DeClercq and Honig, 2011; Drakopoulou Dodd et al, 2014; Spigel, 2013; Tatli et al, 2014). While physical capital is readily operationalised as money and tangible, other forms of capital deemed useful for entrepreneurship are intangible, non-substitutable and have been debated to include organisational, technological, human, cultural, intellectual, social and symbolic (Audretsch and Keilbach, 2004; Bowman and Swart, 2007; Carter et al, 2003; Dollinger, 1995; Erikson, 2002; Foss et al, 2007; Haber and Reichel, 2007; Kim et al, 2006; Leitch et al, 2013; Ram et al, 2008). There is emerging interest in applying Bourdieu's (1986) perspectives on capital which conceives of individuals as competing to acquire the variety of forms of capital needed to secure dominant positions within the 'fields' (social, institutional and market) in which they operate (Drakopoulou Dodd, 2014; KaratasOzkan, 2011; Lee, 2011; Light and Dana, 2013; Scott, 2012; Vershinina et al, 2011). In a Bourdieuian sense, successful entrepreneurship depends on access to a mix of economic, social, cultural and symbolic capitals (Firkin, 2003; Shaw et al, 2008, 2009, 2013).

Of these, Bourdieu (1986) argued that economic capital is the most important. Regarding cultural capital, Bourdieu (1986, 1993) theorised three forms: embodied cultural capital comprises of long lasting personal dispositions which influence actions, helping individuals 'sense make' (DeClercq and Voronov, 2009a, 2009b; DeClercq and Honig, 2011; Lee, 2011; Light and Dana, 2013; Nowicka, 2013; Scott, 2012); objectified cultural capital which takes the form of materials, products and items of culture such as books and paintings (DeClercq and Voronov, 2009a, 2009b; DeClercq and Honig, 2011; Vershinina et al, 2011); and institutionalised cultural capital which includes qualifications and work experiences (DeClercq and Voronov, 2009a, 2009b; Law and Mooney, 2012; Shaw et al, 2013; Vershinina et al, 2011). Bourdieu (1986) considered social capital as the total of all actual and potential resources which can be acquired via a network of durable relationships. Definitions of social capital have been much contested with debates considering whether social capital can be possessed by an individual or a collective (Burt, 1992; Coleman, 1988; Coradini, 2010; Kwon and Adler, 2014; Lin, 1999; Nahapiet and Ghoshal, 1998; Putnam, 2000; Woolcock and Narayan, 2000) and whether bonding or bridging networks are most relevant for entrepreneurship (Anderson and Jack, 2002; Cooke et al, 2005; Davidsson and Honig, 2003; Lee and Jones, 2008; Martinez and Aldrich, 2011; Mosey and Wright, 2007; Murphy et al, 2015; Stam et al, 2014). The final form of capital, symbolic or reputational, refers to others' recognition that the economic, cultural and social capitals possessed by an actor are legitimate and credible (Bourdieu, 1986, 1990a, 1990b, 1998). This type of capital can be objectified in the form of awards and public recognitions (Bourdieu, 1986, 1998), but its practical value is determined by assessments others make about the extent to which the forms of capital entrepreneurs command are sufficient for them to be recognised as 'legitimate' (O'Cass and Sok, 2013; Stringfellow and MacLean, 2014; Sutherland and Burton, 2011). 


\section{Theory of Entrepreneurial Occupations and Capital}

Bourdieu (1993:233-234) described a genetic sociology where an individual's life course and choice of occupation are 'socially conditioned', shaped in childhood by the effects of 'family milieu'. Erickson (1996:245) disagrees, arguing that 'one's own class trajectory and working experience', especially 'current' occupation relate to advantages, rather than early life or family milieu. However, both concur that current occupation relates to wealth, power and cultural resources. Occupation refers to distinct work activities and influences socio-economic status (Watson, 2008). For Bourdieu (1986:52), persons 'richly endowed with capital (mainly social, but also cultural and even economic capital)' are typically more productive, known and recognised. Indeed, scientists, liberal professionals, industrialists, professors and artists are 'holders of a great volume of overall capital...are opposed, in the mass, to those who are most deprived of economic and cultural capital, such as unskilled workers' (Bourdieu, 1998:7). Knowledge workers are typically highly intelligent and establish diverse social networks to enhance their employability (Adler et al, 2008; Erickson, 1996; Kennedy, 2004; Smith, 2010). Social agents who follow the same occupation may exhibit similar habitus such as appreciations, tastes and stylistic thinking (Bourdieu, 1990a, 1990b; Tatli and Ozbilgin, 2012). ${ }^{3}$

The links between self-employment and occupational classification are seldom studied (Astebro and Thompson, 2011; Greenman, 2011; Lechmann and Schnabel, 2014; Monsen et al, 2012). Like employment, self-employment is characterised by 'the kinds and combinations of skills that are necessary' (Lazear, 2005:651). Furthermore, the linkage between different types of self-employment based on occupational classification and non-material capitals is understudied, primarily focused on social capital (DeClercq and Voronov, 2009a, 2009b; Light and Dana, 2013; Tatli et al, 2014). For example, Kalantaridis and Bika (2006) demonstrate that opportunity-driven and professional entrepreneurs develop exogenous networks, while craft-based entrepreneurs prefer local and parochial networks. Similarly, Anderson and Miller (2003) and Barbieri (2003) demonstrate that professional entrepreneurs have better quality networks containing more instrumental resources than those possessed by less skilled entrepreneurs. Interestingly, though, Jayawarna et al (2014:931) demonstrate that 'high family socio-economic status' and 'higher parental involvement in childhood education' predict adulthood business ownership.

It is clear from the literature review that the non-material capitals (cultural, social and symbolic) of different entrepreneurs by occupational classification is understudied.

\section{Method}

\section{Sample and Respondents}

This research reflects a convenience sample population. That is, two nationally important and dissimilar enterprise-training programmes funded by the 1997-2010 Labour government participated in the study. Thus, nascent entrepreneurs on the Science and

\footnotetext{
${ }^{3}$ Bourdieu (1990a:131-132) suggested, 'the habitus implies a 'sense of one's place' but also a 'sense of the other's place'. For example, we say of an item of clothing, a piece of furniture or a book: 'that's pettybourgeois' or 'that's intellectual'...it presupposes that taste (or the habitus) as a system of classificatory models is objectively referred'.
} 
Enterprise Challenge (SEC) and nascent entrepreneurs residing in deprived areas on the New Entrepreneurship Scholarship (NES). ${ }^{4}$ Scarcity of datasets regarding occupationally distinct entrepreneurs and non-material capitals, and ease of access were the main reasons for adopting convenience sampling. The SEC represents an attempt to stimulate and train value added scientific, technical and professional entrepreneurs (Delcloque and Auckland, 2004; DTI, 2000; Kothari and Handscombe, 2007; SQW, 2005). It is congruent with the 2010-2015 Coalition providing focussed support for innovative and high potential new businesses (BIS, 2011, 2014; House of Commons Cm 9039, 2015; White Paper, 2010) and current Conservative Government's ambitions to further help new businesses strive and grow (BIS/15/498, 2015). The NES provided training to individuals residing in multiply deprived areas, because of the lack of employment opportunities (DfES, 2003; Jones and Jayawarna, 2010; Lee et al, 2011; Rouse and Jayawarna, 2006; Slack, 2005; Taylor et al, 2004; UKCES, 2011). However, new businesses promoted by NES were primarily low turnover and operating in personal or community services, retail, wholesale and manufacturing with a service element (Jayawarna et al, 2007; Learning and Skills Council, 2007). By comparison, the types of new businesses promoted by the more recent New Enterprise Allowance (NEA) scheme for any unemployed individual were 'providing services such as landscape gardening, painting and decorating, hair and beauty and building services' (DWP, 2013:56). It seems that new businesses started by the unemployed and those residing in deprived areas are a bulwark of non-professional selfemployment.

The sampling frame represents a cohort of nascent entrepreneurs on SEC and a cohort of nascent entrepreneurs on NES at two universities in 2006/7. This is similar to Arshed et al (2014:647) collating interview data about policy implementation 'towards the end of the Labour administration in 2009-10'. The course directors selected 10 respondents from each cohort and the procedure of substitution followed to handle nonparticipation. A total of 20 respondents participated. We are confident that the sampling population and frame, and course directors selecting respondents captured robust and reliable data insights. Inductive smaller scale studies rarely provide certainty, but our sample is in line with important research conducted by Vershinina et al (2011) that sought 10 Polish entrepreneurs from snowball sampling local clubs and shops. In addition, it converges with Scott's (2012) sample of 25 cultural entrepreneurs from snowball sampling the local music industry.

Table 1 summarises the SEC and NES respondents' occupational classification according to the European Socio-economic classification (ESec) (see Eurosec Matrix User Guide). The ESec reclassifies the International Standard Classification of Occupations (ISCO88) three-digit codes and represents a dichotomous self-employment occupational classification. Thus, SEC respondents are classified as 'professional and higher technician', while NES respondents are categorised as 'non-professional'. Such a

\footnotetext{
4 Accordingly, nascent entrepreneurship indicates early gestation activities and venture creation competence-success e.g business registration, financing, launch, early sales and income (Davidsson and Honig, 2003; Obschonka et al, 2011; Samuelsson and Davidsson, 2009). Furthermore, Obschonka et al (2011:122) suggest that 'emerging ventures' differ in terms of the 'pace' with which they are launched and achieve sales, and this is common across our SEC and NES convenience sample.
} 
classification is similar to the recent work of Lechmann and Schnabel (2014:64) who categorise the self-employed as either 'liberal professionals (freiberuflich Tatige)' or 'tradesman (Selbstandige)'. Sub-groups within the SEC and NES respondents are visible, similar to previous related studies. ${ }^{5}$ Of the SEC participants, six were associated with primarily technology-scientific activities and four largely reflect professional-design activities. For the NES sample, we found institutionalised cultural capital (previous qualifications) differs with five respondents educated to Degree level, three possessing GCSEs and two having no qualifications. For Klyver and Foley (2012:584), considering 'sub-culture' or visible sub-samples represents more typical and reliable findings.

\section{-----Insert Table 1 here-----}

\section{Data Collection and Analysis}

Bourdieu (1990a:126) argued that researching non-material forms of capital is a challenge and 'subjective representations' are an entry point into the social world of the actors being investigated. Because of limited empirical research in the context of entrepreneurship, 'it is hard to operationalise Bourdieu's constructs' (Karatas-Ozkan, 2011:902). There is a great need to collect inductive data that represents an entrepreneur's multiple everyday practices, or unknown live capital (Dana and Light, 2011; Drakopoulou Dodd, 2014; Light and Dana, 2013; Spigel, 2013). On this basis, subjective qualitative data is appropriate to consider the non-material capitals relevant for different entrepreneurial types. Simply put, 'these intangibles are invisible to the eye and not easily measured' (Svendsen and Sorensen, 2007:453).

Semi-structured interviews were conducted as they promote opportunities for entrepreneurs to shape findings (Finch et al, 2010; Karatas-Ozkan, 2011). Interviews lasted between 45 and 120 minutes. A combination of closed and open-ended questions, and probes and prompts were used. Bourdieu's (1986) Capital Theory informed the interview instrument and respondents were asked to illuminate: culturally objectified affiliations with machines or materials and dispositions connected to work and life; social connections and networking; and symbolic reputation or being cognizant of others. As some aspects of social capital (network size, composition) can more systematically be captured through quantitative data (Grootaert et al, 2004), a face-to-face name generator questionnaire was used immediately prior to interviews. ${ }^{6}$

\footnotetext{
${ }^{5}$ For example, SEC primarily promoted scientific and technical entrepreneurship (Delcloque and Auckland, 2004; SQW, 2005). However, it focused on bridging knowledge-driven disciplines, consultancy and specialist design (Kothari and Handscombe, 2007). The NES represents a multiplicity of demographic variation (UKCES, 2011) that is not possible to consider in this study. That said, Jayawarna et al (2007) and the Learning and Skills Council (2007) both point out proportionately similar levels of participants educated to at least NVQ level 4 (e.g. HND, Degree) and those below.

${ }^{6}$ The respondents were asked to freely list and then categorise each alter according to relationship type, and were provided with further opportunities to recall and record any relevant alters during and at the end of the interviews (Adams et al, 2006). We adopted Barbieri's (2003) approach and developed the following variables: family alters (family, partner); friend alters (friend); close acquaintance alters (current/previous work colleague, SEC/NES colleague); and high-status bridging alters (business contact, SEC/NES advisor, professional advisor). Pooling alters freely recalled by both entrepreneurial groups (professional and higher technician $n=180$, non-professional $n=130$ ) enables statistical analysis of actual network structural composition (Agndal et al, 2008).
} 
The main interpretive analysis involved the recording and transcription of interviews, and coding and categorisation of textual data into meaningful units (Denzin, 1994; Guba and Lincoln, 1989). This reduced data and identified key emerging analytical themes (see Figure 1). Selecting quotes facilitates a coherent and logical narrative concerning subjectively driven non-material capitals (Lee, 2011; Ram et al, 2008; Scott, 2012; Vershinina et al, 2011). A broad range of quotes from the full range of respondents is provided to offset the problems of researcher and selection bias. The supplemental quantitative name-generator questionnaire data was analysed through Cramer's $V$ (strength of association) to augment the qualitative analysis of social capital. It was impossible and infeasible to control for demographic variation in our inductive research. However, we compare findings both between and within the 'professional and higher technician' respondents and 'non-professional' respondents according to the aforementioned visible sub-samples.

\section{-----Insert Figure 1 here-----}

\section{Findings}

Cultural capital and objectified affiliations. The concept of 'objectified affiliations' reflects the relevance of products, goods and materials deemed useful for different types of entrepreneurship. Our data demonstrates that objectified affiliations differ between 'professional and higher technician' and 'non-professional' respondents, the latter of whom reside in multiply deprived neighbourhoods. The former cohort affiliates with sophisticated and novel products, goods and materials reflecting their exploitation of value added knowledge-driven opportunities. For instance, Jon indicates an affiliation with dynamic internet business activities, "It is a web-based business at the moment. It is teaching people how to do things for the home, for the garden, childcare and cooking...It is a knowledge bank". Affiliation with internet and software business activities implies high potential, novelty and quality opportunities. As Ian explains,

"I am trying to fuse technology with healthcare as the NHS are unable to deal with modern technology and change...It is basically a supportive tool where physios act in a virtual way".

It is also argued that affiliating with a broad range or 'combination' of value added products, goods and materials could enhance returns for 'professional and higher technician' respondents. In this sense, Jason affiliates with both design and consultancy activities, "I design a range of my own lighting and furniture products...working on a consultancy basis as well". He also tells us that the, "work is based on familiar objects and challenging materials". Similarly, Dan affiliates with both specialist design and education, "I use my design ideas as a vehicle to go in and educate...the things I design are to do with the fact that I am an environmentalist". He also enhances the possibilities for economic rents, because "some of the things become art objects as well". This distinct affiliation with a 'combination' of value added products, goods and materials has the potential to translate to better productivity, turnover and profit. Thus, Zobair affiliates with "Bluetooth tagging" and pursues supplemental value added opportunities such as "electronic tagging... and another one to do with location tagging and websites". While 
Michelle notes, "The idea is to be a consultant around the issues around dyslexia'. In addition, she points out, 'I want to help diagnose".

The 'non-professional' respondents residing in multiply deprived neighbourhoods affiliate with generic products, goods and materials. That is, their objectified affiliations reflect less distinctive and differentiated new businesses. For example, Tanzella is "doing a cake business now, so just various short courses". While Karina explains, "I know it is still photography, but I want to be getting a proper rate of pay, just basically attracting jobs that pay properly". Furthermore, Simon tells us about a strong affiliation with basic goods, risk avoidance and necessity self-employment,

"I wanted to open an organic café but I thought it was going to be expensive, and it is going to be hard work...So what I thought was you know. I may as well start at the bottom and do catering...we are going to Costco, we are getting the cheapest burgers you can".

For some 'non-professional' respondents residing in multiply deprived neighbourhoods, personal circumstances, hobbies and previous work experiences influence their affiliations with generic products, goods and materials. Thus, it emerges that Arun "was bored of $\mathrm{M} \& \mathrm{~S}$ " retail work and this influenced his decision to launch "Therapies" - a reflexology and Indian head massage business. He also says, "I thought I might as well do something I like and get paid for it". Also, Jon stresses that his decision to launch a bar/café in North West England was influenced by previous employment, "I want to have like just a huge counter with some big fridges behind to serve just bottles, so it is easy in and out, do you know what I mean... Relevant to my business. I have worked and done a lot of time in hospitality... I have worked as a team leader in bars".

Cultural capital and embodied dispositions. The concept of embodied or personal dispositions refers to commonly held personal assumptions and conceptions about work and life. It appears that embodied dispositions differ between 'professional and higher technician' and 'non-professional' respondents residing in multiply deprived neighbourhoods, except for some relatively small within-differences in the latter entrepreneurial group. Across the two cohorts of nascent entrepreneurs, 'professional and higher technician' respondents refer to an embodied disposition for growth orientation and driven business ownership. For Sunit, strong business performance is essential "I basically want it to succeed and grow and gather lots of experience that you can get from doing it". Likewise, Michelle exemplifies this aspiration to grow, "I am hoping to see the business grow the more I research and specialise". It is noteworthy that Mohamed is considering internationalising "in the long-term". Indeed, Zainfur expressed his appreciation for growth and proudly stated, "I personally think it is going to be very successful. I actually think I am going to be overloaded and will not be able to handle the volume".

To achieve growth, the 'professional and higher technician' respondents also develop an embodied disposition for scalability which links with growth prospects. We find that strategising and scenario planning are evident across this sample. For example, Zobair aspires to "set-up a network...get a kind of monopoly going" and "extend into e- 
vouchers". While Jon outlines a specific strategy to transform his web business "into a book" and "diversify into different types of media". Learning and curiosity is important as captured by Jason's description that he questions himself constantly, "you know, look into this question mark, what is this question mark".

By contrast, 'non-professional' respondents residing in multiply deprived neighbourhoods prioritise an embodied disposition for survivability. This reflects predominant assumptions and conceptions about the challenges and hurdles when launching a new venture. This was particularly prevalent for those respondents without a degree. Tanzella suggests, "I want to survive. Just get more publicity and get regular customers...At the moment it is just word of mouth". While Simon strongly suggests that his takeaway business will help him to endure and continue family life, "It is going to help put a roof over mine and my daughters head and that is all". Furthermore, our nonprofessional respondents residing in multiply deprived neighbourhoods reinforce low scalability, expressing limited desire for growth and a greater focus on personal motivations. Rather than acquiring a small loan or funds to purchase a portacabin, Arun prefers home visits to practice Indian head massage, "I do not really need one, I can just go into people's homes". There is a reluctance to embrace strategising and growth orientation which could reflect assumptions and perceptions about the constraints of their business or themselves. For example, Simon dismisses projections explaining, "you may as well light a match and throw them in a bin...I do not want to think ahead". Likewise, Kay rejects planning, stating "I am not very good at planning ahead. I would like to sort of take things as they come".

However, it is also important to point out that not our entire sample of "nonprofessional' respondents residing in multiply deprived neighbourhoods felt they were restricted to survivability. The data suggests that those with a degree develop an embodied disposition for survivability, but some cautious growth. Karina aspired to grow, but was hesitant and uncertain, "I want within three years to not be having to do much, what I call bread and butter work, which is like the work I am doing at the moment...I am hoping that I will not have to do it... I want to be getting the kind of work that suits my style really". Jon prioritises survivability and indicates that aspirations are healthy, "I just need to be looking at finding a decent location, you know just keep it simple for the first year or so and just try and make enough money...but I think maybe there is potential to have at least maybe a couple (bars)". In addition, Kristan speaks about a desire "to survive, to be reputable, in five years' time, I want to be known for doing decent quality design work".

Social capital. Social capital reflects the structure and diversity of network relations, and facilitates access to resources. Our data shows that social capital differs between the two cohorts, with 'professional and higher technician' respondents primarily emphasising the importance of bridging ties to 'get ahead'. Bridging ties enhance the heterogeneity of resources and are necessary for knowledge-driven activities. Indeed, Georgina tells us about the importance of speculative bridging for material resources, "With the larger companies, I have been able to just send them an e-mail...do you have this and this and this, and they will send me samples". For Zainfur, being a member of a computer-programming forum (JavaRanch) provides access to expert information and knowledge, "The people of the Web Board are useful for getting straight to the core of the 
problem". He further notes, "when I am on the message board it is unbelievable and I would pay for that service again". There are incentives to actively seek bridging opportunities, but perseverance is needed. As Zobair explains, "It is just something I have learned getting out there. Most of the networks were through just getting out there". It appears that bridging also stimulates intellectual development reflected by Dan's comments on the importance of influential industry bridges that act as information providers and role models,

"Time goes by and they consistently on request supply information, but again, because they are all designers in their own right, as well as business partners they continue to be role models".

In contrast, 'non-professional' respondents residing in deprived neighbourhoods reveal they are heavily reliant on bonding ties which reflect peer interactions, mutual solidarity and communal values. Local neighbours are important sources of mutual and reciprocal support. As Tanzella explains, "My neighbour CF was diagnosed with breast cancer last year. I have been supporting her because she lives on her own...CF is really good because she has helped me all the way with this". Community and reciprocity is essential for strong bonding. For instance, Paula comments, "Some of the people I know socially...there is probably a bit more there because I want to give them something". She also tells us about the pivotal role of family relations and long-term emotional support, "My brother, he is emotional support as well, and information...I am very close to my brother so there is quite a strong bond there". Communal bonding can even facilitate informal loans and Martin draws on a local friend for financial support, "He is a local friend of mine, he said to me yesterday...He said to me, this business are you looking for investment? I said yes, well every business is looking for investment...He said I am talking about a little investment".

Moreover, the 'non-professional' respondents residing in deprived neighbourhoods are reluctant to develop bridging social capital. An over reliance on bonding reinforces parochialism and 'getting by'. In this regard, Paula indicates a strong opposition to bridging, "That is why they are not on the list (name generator). That kind of person...I am not one for hierarchy anyway...so I have no concept of hierarchy and I get in trouble sometimes". While Kevin stresses that close bonding ties are irreplaceable in his network, "every person who is not a family member is someone I have met personally". He prioritises bonding social capital and emphasises bridging, though to a much lesser extent, "I am going to send some information to some of the companies that are there (business park), because some are very small”. Reluctance to bridge could lead to a critical deficiency of valuable and divergent resources. For instance, Simon was particularly reluctant to bridge,

"I do not trust the banks. I do not trust my own bank. I do not trust anyone. I trust myself and that is it...Right now, until everything gets to a certain stage, then I will not be thinking about getting out there and using networking or funding".

The freely recalled quantitative name generator data converges with the main qualitative interview data and highlights a strong association between 'professional and 
higher technician' respondents and bridging, and 'non-professional' respondents residing in deprived neighbourhoods and bonding (Cramer's $V .264$, p.000). ${ }^{7}$ There are no within significant differences. Education has little influence on social capital within the "nonprofessional' respondents. This is similar to the assertions of Samuelsson and Davidsson (2008) that human capital is unimportant for imitative ventures. While collapsing the 'professional and higher technician' respondents into 'professional' or 'higher technician' has little effect on social capital, this suggests the validity of the ESec.

Symbolic capital. This form of non-material capital represents symbolic actions regarding reputation and recognition. Our data demonstrates that 'symbolic capital' differs between 'professional and higher technician' and 'non-professional' respondents residing in multiply deprived neighbourhoods, with the former emphasising sustaining external legitimacy and market driven reputation. To achieve this, attracting investment from funding networks was necessary. As such, Dan tells us about the symbolic act of acquiring funding from both private and social investors to grow the business, "I was lucky enough to get some funding from the Community Foundation for Greater Manchester and a company called Unlimited". He also suggests that funding streams helped him to 'develop products' and 'deliver payment and profit through developing workshops'. Similarly, Jason tells us about the reputation and funding benefits of attending elite cultural events - "exhibitions, that is the big factor for talking to potential customers, people who are important or who could support me or support agencies". For these high potential respondents, external visibility through conveying seriousness, credibility and competence is essential. Indeed, Zainfur explains, "The business exchange conference was good for how to provide your business card and what to write on your business card". Moreover, Jon demonstrates a determination to develop a reputation based on being instrumental and calculative in some business situations, "There has been a few people in business meetings that I have gone in there solely for the business, the purpose of the business, and nothing else, and walked out".

The 'non-professional' cohort residing in multiply deprived neighbourhoods prioritise the symbolic action of personalisation, enjoyment and fun in the workplace. This perhaps reflects a symbolic attitude for affective routines, and less awareness and taking notice of formal business reputation. In this sense, Karina prefers a workplace environment that facilitates informality and fun, "Since I started the project. I have noticed that even to people I do not know all that well, things do just not stay formal...they should be fun". Likewise, Tanzella stresses the importance of informality, fun and personal motivations, "I would speak to my sister so...she would get me all the research and help me come to a decision on which is the best cake design... And it is fun to do it like that. So it does not feel like work". For Simon, retaining control, reinforcing parochialism and avoiding formalisation is important, "I want to do it myself. I want to control every aspect

\footnotetext{
7 We observe the following: 'family alters' (professional and higher technician 13.3 per cent, nonprofessional 26.9 per cent); 'friend alters' (professional and higher technician 10.0 per cent, nonprofessional 20.8 per cent); 'close acquaintance alters' (professional and higher technician 18.3 per cent, non-professional 16.9 per cent); and 'higher status bridging alters' (professional and higher technician 58.3 per cent, non-professional 35.4 per cent). There is a strong association between entrepreneurial group and network structure (Cramer's $V .264$, p.000).
} 
of my business...I have not got to be anyone else other than me". He also points out, "I just want to stay plain and simple". They reinforce personalisation in everyday business situations, or as is practically possible to do so. Thus, Kevin explains that being assertive and forceful in business settings is incompatible with his personal value system, "When I initially meet someone I might not come across very well... I would not say 'I am assertive'. I do not like to ram it down people's throats. Sometimes that is a bad move in a sense, because I am not selling myself'.

In table 2, we summarise the non-material capitals (cultural, social and symbolic) of our distinct cohorts of entrepreneurs: professional and higher technician respondents; and non-professional respondents residing in multiply deprived neighbourhoods.

-----Insert Table 2 here-----

\section{Discussion}

There is an emerging interest in understanding the role of Bourdieu's (1986) nonmaterial forms of capital (cultural, social and symbolic) in the entrepreneurial process (DeClercq and Voronov, 2009a, 2009b; DeClercq and Honig, 2011; Drakopoulou Dodd et al, 2014; Spigel, 2013; Tatli et al, 2014). Much prior research demonstrates the importance of the social capital that underlies successful entrepreneurship (Anderson and Jack, 2002; Anderson and Miller, 2003; Anderson et al, 2007; Cooke et al, 2005; Davidsson and Honig, 2003; Martinez and Aldrich, 2011; Stam et al, 2014; Westlund and Bolton, 2003). However, the relevance and nature of cultural and symbolic capitals in the entrepreneurial process have received little dedicated empirical research (Drakopoulou Dodd, 2014; Karatas-Ozkan, 2011; Lee, 2011; Light and Dana, 2013; Scott, 2012; Shaw et al, 2013; Vershinina et al, 2011). Moreover, the accumulation of non-material capitals in the context of occupationally different self-employment is understudied (DeClercq and Voronov, 2009a, 2009b; Light and Dana, 2013; Tatli et al, 2014). Consequently, we consider these gaps and contribute a comprehensive examination of Bourdieu's nonmaterial capitals in the context of distinct nascent entrepreneurs by occupational classification. DeClercq and Honig (2011:357) regard non-material forms of capital as an entrepreneur's 'ability' and in this sense, the thrust of our findings show that professional and higher technician entrepreneurs are more able to thrive and grow than nonprofessional entrepreneurs.

Social capital is critical for start-up and professional and higher technician entrepreneurs predominantly build bridging networks, while non-professional entrepreneurs prefer to bond, which reinforces parochialism. These findings are consistent with both Anderson and Miller's (2003) and Barbieri's (2003) studies. Concerning the understudied dynamics of cultural capital, our findings demonstrate that professional and higher technician entrepreneurs affiliate with products, goods and materials that are sophisticated and novel. This chimes with Scott's (2012) account of thriving cultural entrepreneurs. We also illuminate an unknown feature of professional and higher technician entrepreneurs' cultural capital and show they develop embodied dispositions for growth orientation and scalable businesses. In contrast, non-professional entrepreneurs are found to affiliate with products, goods and materials that are generic, suggesting less innovation intensive and less able new businesses (Blackburn and Ram, 2006; Jayawarna 
et al, 2007). Furthermore, non-professional entrepreneurs primarily develop an embodied disposition for survivability and low scalability revealing an unknown perspective on cultural capital. However, given small within-group differences, it may be that institutionalised cultural capital influences ways of thinking as non-professionals with a degree qualification did exhibit cautionary growth ambitions. This is in line with Pickernell et al's (2011) graduate entrepreneurship study. We are one of the first studies to demonstrate that symbolic capital reflects 'an act of cognition which enforces recognition and which, quite often, tends to affirm what a person or thing is' (Bourdieu, 1990a:136). Thus, we demonstrate new findings about non-professional entrepreneurs' preferences for more personalised and less formal businesses, and professional and higher technician entrepreneurs' desire to signal legitimacy to the market.

\section{Policy Recommendations}

Enterprise policies are often 'made implicitly', with politicians and advisors not aware of specific factors that may constrain or enable their implementation and success (Storey and Greene, 2010:401). The role of intangibles, including we argue non-material capitals, in the entrepreneurship process is overlooked in policy debates (BIS, 2011, 2013; Capelleras et al, 2011; OECD, 2014). In addition, the needs and preferences of different entrepreneurial types deserve greater attention in business enterprise interventions (Arshed et al, 2014; EC, 2013; Mason and Brown, 2013). Policymakers and 'Government should strive to improve the schemes in place and make them flexible enough to meet business needs' (House of Commons Cm 9039, 2015:21). Against the backdrop of enterprise policy under the 2010-2015 Coalition and current Conservative government, we propose recommendations with respect to Bourdieu's (1986) non-material capitals (cultural, social and symbolic) that underlie professional and higher technician entrepreneurship, and non-professional entrepreneurship.

Factors associated with high potential and innovative entrepreneurship are complex and there is no 'clear guide for policy' (Nesta, 2011:12). According to Wright et al (2015), growth enabling policy development is a priority for Government. From the data, we provide insights for policymakers to better promote high potential entrepreneurship such as higher technician and professional start-ups:

- Foster the conversion of professional and higher technician start-ups valuable cultural capital into disruptive tendencies. Policies targeting high potential entrepreneurship need to provide guidance on the importance of cultural capital, because 'agility' is necessary to innovate (House of Commons $\mathrm{Cm}$ 8980, 2014:5). In particular, guidance on embodied dispositions to grow and the pursuit of related and unrelated opportunities are likely to enhance disruptive tendencies. The 'Business Growth Service', 'Great Business Scheme' and 'Local Enterprise Partnerships' (LEPs) are obvious strategic interventions that should nurture this cultural feature (House of Commons $\mathrm{Cm}$ 9039, 2015; House of Commons SN/EP/5651, 2015; www.gov.uk/businessgrowth-service). 
- Continue to link professional and higher technician start-ups with specialistinstitutionalised networks. Bridging social capital plays an important role in high potential entrepreneurship and existing support infrastructures such as 'Catapult Centres', 'Knowledge Transfer Networks' and 'Innovate UK blog' should continue to provide specialist networked opportunities (BIS, 2014; House of Commons Cm 8980, 2014; House of Common Cm 9039, 2015).

- Invest in professional and higher technician start-ups that have already attracted funds, and influence symbolic reputation. Regarding finance for innovative new firms, 'there is still more to do' (House of Commons Cm 8980, 2014:60). Policymakers should prioritise and fast track loans to new firms that have already acquired funds and reputational advantages, and speed up their growth. This suggests that fiscal initiatives such as the 'Enterprise Finance Guarantee' and 'Small Business Research Initiative' should screen applicants for symbolic reputation and commercial legitimacy (BIS, 2015; House of Commons Cm 9039, 2015).

For Nesta (2011:10), 'most start-ups start small and either stay small or die'. Startups by the unemployed and in deprived areas face additional challenges (GOV.UK Press release, 2015). So, there are some insights from the data for policymakers to better support non-professional start-ups by both the unemployed and in deprived areas with high unemployment, and more generally:

- Press business support mentors to equip non-professional start-ups with more valuable cultural and social capitals. Policymakers must recognise the need to enhance or stimulate the cultural and social capitals of non-professional entrepreneurs. To address non-professional entrepreneurs' survival disposition, restricted, cautious growth ambitions and insufficient bridging, the mentoring support provided through 'Local Enterprise Partnerships' (LEPs) should promote an awareness of culturally divergent thinking, instil selfconfidence and encourage speculative bridging (House of Commons SN/EP/5651, 2015; White Paper, 2010). Given criticisms of the LEPs overdependence on voluntary inputs and preference for big businesses, this will be a challenge (Adonis Review, 2014; Bennett, 2012; Centre for Cities, 2013; Work Foundation, 2012). However, addressing the restrictive cultural and social capitals of non-professionals could maximise returns on already time-constrained voluntary input. Moreover, the DWP (2013:56-62) acknowledge that poor quality businesses funded by the 'New Enterprise Allowance' (NEA) lack 'capitals' and this suggests a need to better promote the benefits of valuable cultural habits and bridging.

- Press business support mentors to raise awareness of the importance of symbolic reputation to non-professional start-ups. Insufficient symbolic capital implies a failure or unwillingness to be aware of others assessments in the marketplace. Therefore, mentoring support provided by both the NEA and 
LEPs should encourage non-professionals to be cognizant of others assessments and promote reputation management workshops, events or forums. Given the continuation of the NEA and role of LEPs in addressing worklessness (House of Commons SN/EP/5651, 2015; House of Commons $\mathrm{SN} / \mathrm{EP} / 05878,2015)$, it seems important that mentors raise an awareness of reputation management.

\section{Limitations and Future Research}

The relatively small sample size and cross-sectional nature of respondents restricts the scope and generalisability of our findings. There is a need for more research using larger samples of demographically diverse and cross-cultural nascent entrepreneurs not registered on government schemes. That said, we considered visible within sub-groups and reported any differences. With regard to the non-professional entrepreneurs residing in deprived areas, we are unable to determine whether the deprived locality has any effect as we do not have a sample of non-professionals residing in areas that rank low for deprivation. Yet we did make clear that enterprise schemes for the unemployed and those residing in deprived areas with high unemployment are an important source and bulwark of new non-professional businesses (DWP, 2013; Jayawarna et al, 2007; UKCES, 2011). While the reliability of qualitative interview data is always seen as potentially, selfreferential, but like Vershinina et al (2011:105), our intention was to 'make analytical, not statistical generalisations'. Finally, it is possible that the supplementary self-reported quantitative ego-alter data suffers from response bias and over estimation of network structure.

As growth ambitions may not be static and could change over time, it is recommended that future research considers the relationships between occupationally distinct self-employment and non-material capitals during the early, developmental and establishment stages of business enterprise. It is also recommended that the links between occupation, non-material capitals and business performance be examined. How each form of non-material capital can be converted into another distinct form of capital also merits further investigation. Finally, Audretsch and Keilbach (2004:424) suggest that 'a broad spectrum of 'non-trivial' factors...influence entrepreneurial capital'. This implies investigating the role of life course factors (Rouse and Jayawarna, 2011) in the study of entrepreneurial capital.

\section{References}

Adams A, Madhaven S, Simon D, 2006, "Measuring social networks cross-culturally" Social Networks 28 363-376

Adler P, Kwon S, Heckscher C, 2008, "Professional Work: The Emergence of Collaborative Community" Organization Science 19 359-376

Adonis Review, 2014, Mending The Fractured Economy - Smarter state, better jobs Final report of the Adonis Review available at: http://www.policynetwork.net/publications/4695/Mending-the-Fractured-Economy 
Agndal H, Chetty S, Wilson H, 2008, "Social capital dynamics and foreign market entry" International Business Review 17 663-675

Anderson A R, Jack S L, 2002, "The articulation of social capital in entrepreneurial networks: a glue or a lubricant?" Entrepreneurship \& Regional Development 14 193-210

Anderson A, Miller C, 2003, "Class matters: human and social capital in the entrepreneurial process” Journal of Socio-Economics 32 17-36

Anderson D, Tyler P, McCallion P, 2005, "Developing the Rural Dimension of BusinessSupport Policy” Environment and Planning C 23 519-536

Arshed N, Carter S, Mason C, 2014, "The ineffectiveness of entrepreneurship policy: is policy formulation to blame?" Small Business Economics 43 639-659

Astebro T, Thompson P, 2011, "Entrepreneurs, Jacks of all trades or Hobos?" Research Policy 40 637-649

Atherton A, 2006, "Should government be stimulating start-ups? An assessment of the scope for public intervention in new venture formation" Environment and Planning C 24 $21-36$

Audretsch D, Keilbach M, 2004, “Does Entrepreneurship Capital Matter?" Entrepreneurship Theory and Practice 28 419-430

Audretsch D, 2007 The Entrepreneurial Society (Oxford University Press, Oxford)

Barbieri P, 2003, "Social Capital and Self-Employment: A Network Analysis Experiment and Several Considerations" International Sociology 18 681-701

Bebbington A, 1999, "Capitals and Capabilities: A Framework for Analyzing Peasant Viability, Rural Livelihoods and Poverty" World Development 27 2021-2044

Bennett R, 2008, "SME Policy Support in Britain since the 1990s: What have we Learnt?" Environment and Planning C 26 375-397

Bennett R, 2012, Government LEPs Ill-Equipped To Deliver Policies For Growth available at: www.britac.ac.uk/news/news.cfm/newsid/698

Bennet R, 2014 Entrepreneurship, Small Business and Public Policy: Evolution and Revolution (Routledge, Abingdon) 
Blackburn R, Smallbone D, 2011, "Policy Support for SMEs" Environment and Planning C $29571-576$

Blackburn R, Ram M, 2006, "Fix or fixation? The contributions and limitations of entrepreneurship and small firms to combating social exclusion" Entrepreneurship and Regional Development 18 73-89

Bourdieu P, 1986, "The Forms of Capital", in Handbook of Theory and Research for the Sociology of Education Eds J Richardson (Greenwood, New York) pp 241-258

Bourdieu P, 1990a In Other Words (Polity Press, Cambridge)

Bourdieu P, 1990b The Logic of Practice (Polity Press, Cambridge)

Bourdieu P, 1993 The Field of Cultural Production (Polity Press, Cambridge)

Bourdieu P, 1998 Practical Reason, (Polity Press, Cambridge)

Bowman C, Swart J, 2007, "Whose Human Capital? The Challenge of Value Capture When Capital is Embedded" Journal of Management Studies 44 488-505

Brooksbank D, 2008, "Small Business Policy and Support" Environment and Planning C $26287-291$

Brown R, Mawson S, 2015, "Targeted support for high-growth firms: Theoretical constraints, unintended consequences and future policy challenges" Environment and Planning $C$ doi $0263774 X 15614680$

Burt R S, 1992 Structural Holes. The Social Structure of Competition (Harvard University Press, Cambridge MA)

Capelleras J, Contin-Pilart I, Larraza-Kintana M, 2011, "Publicly funded prestart support for new firms: who demands it and how it affects their employment growth" Environment and Planning C 29 821-847

Carter N M, Brush C G, Greene P G, Gatewood E, Hart M M, 2003, "Women entrepreneurs who break through to equity financing: the influence of human, social and financial capital" Venture Capital 5 1-28

Centre for Cities, 2013, Support for growing businesses: a policy briefing available at: http://www.centreforcities.org/wp-content/uploads/2014/08/13-04-23-Support-forgrowing-businesses-A-policy-briefing.pdf 
Coleman J S, 1988, "Social Capital in the Creation of Human Capital" The American Journal of Sociology: Supplement, Organizations and Institutions: Sociological and Economic Approaches to the Analysis of Social Structure 94 95-120

Cooke P, Clifton N, Oleaga M, 2005, "Social Capital, Firm Embeddedness and Regional Development" Regional Studies 39 1065-1077

Coradini O, 2010, "The divergences between Bourdieu's and Coleman's notions of social capital and their epistemological limits" Theory and methods 49 563-583

Dana L P, Light I, 2011, "Two forms of community entrepreneurship in Finland: Are there differences between Finnish and Sami reindeer husbandry entrepreneurs?" Entrepreneurship and Regional Development 23 331-352

Davidsson P, Honig B, 2003, "The role of social and human capital among nascent entrepreneurs" Journal of Business Venturing 18 301-331

Deakins D, Ram M, Smallbone D, 2003, "Addressing the Business Support Needs of Ethnic Minority Firms in the United Kingdom” Environment and Planning C 21 843-859

DeClercq D, Voronov M, 2009a, "Toward a Practice Perspective of Entrepreneurship" International Small Business Journal 27 395-419

DeClercq D, Voronov M, 2009b, "Role of Cultural and Symbolic Capital in Entrepreneurs' Ability to Meet Expectations about Conformity and Innovation" Journal of Small Business Management 47 398-420.

DeClercq D, Honig B, 2011, "Entrepreneurship as an integrating mechanism for disadvantaged persons" Entrepreneurship and Regional Development 23 353-372

Delcloque P, Auckland D, 2004, "The gestation of nascent enterprises: describing the MSEC experience" Engineering Management Journal 14 46-47

Denzin N K, 1994, “The Art and Politics of Interpretation", in Handbook of Qualitative Research Eds N K Denzin, Y S Lincoln (Sage, Thousand Oaks) pp 500-515

Department for Business Innovation and Skills DBIS, 2011, Innovation and Research Strategy for Growth December 2011 available at: https://www.gov.uk/government/publications/government-innovation-and-researchstrategy

Department for Business Innovation and Skills DBIS, 2013, SMEs: The Key Enablers of Business Success and the Economic Rationale for Government Intervention BIS Analysis Paper No. 2 available at: 
https://www.gov.uk/government/uploads/system/uploads/attachment_data/file/266304/b is-13-1320-smes-key-enablers-of-business-success.pdf

Department for Business Innovation and Skills DBIS, 2014, Innovation Report 2014 Innovation, Research and Growth available at:

https://www.gov.uk/government/uploads/system/uploads/attachment_data/file/293635/b is-14-p188-innovation-report-2014-revised.pdf

Department for Business Innovation and Skills DBIS, 2015, 2010 to 2015 government policy: business enterprise available at:

https://www.gov.uk/government/publications/2010-to-2015-government-policybusiness-enterprise

Department for Business Innovation and Skills DBIS, 2015, BIS/15/498 Enterprise Bill: summary factsheet available at:

https://www.gov.uk/government/publications/enterprise-bill-summary-factsheet

Department for Education and Skills DfES, 2003, Assessing the Effectiveness of New Entrepreneur Scholarships Report - RR410 (DfES Publications)

Department of Trade and Industry DTI, 2000, Excellence and Opportunity a science and innovation policy for the $21^{\text {st }}$ century available at:

http://bis.ecgroup.net/Publications/Science/Science.aspx

Department for Work and Pensions DWP, 2013, New Enterprise Allowance: Qualitative evaluation available at: https://www.gov.uk/government/publications/new-enterpriseallowance-qualitative-evaluation-rr-836

Dollinger, M, 1995, Entrepreneurship: Strategies and Resources (Irwin, Boston)

Down S, 2012, "Evaluating the impacts of government policy through the long view of life history" Entrepreneurship and Regional Development 24 619-639

Drakopoulou Dodd S, 2014, "Roots radical - place, power and practice in punk entrepreneurship" Entrepreneurship and Regional Development 26 165-205

Drakopoulou Dodd S, McDonald S, McElwee G, Smith R, 2014, “A Bourdieuan Analysis of Qualitative Authorship in Entrepreneurship Scholarship” Journal of Small Business Management 52 633-654

Drucker P, 1985 Innovation and Entrepreneurship (Butterworth-Heinemann, London)

Eckhardt J, Shane S, 2003 “Opportunities and Entrepreneurship” Journal of Management 29 333-349 
Erickson B, 1996, “Culture, Class, and Connections" American Journal of Sociology 10 $217-251$

Erikson T, 2002, “Entrepreneurial capital: The emerging venture's most important asset and competitive advantage" Journal of Business Venturing 17 275-290

European Commission EC, 2013, Entrepreneurship 2020 Action Plan available at: http://eur-lex.europa.eu/LexUriServ/LexUriServ.do?uri=COM:2012:0795:FIN:EN:PDF

European Socio-economic Classification ESEC "ESeC Class" available at: https://www.iser.essex.ac.uk/archives/esec/user-guide/the-european-socio-economicclassification

Foss K, Foss N, Klein P, Klein S, 2007, "The Entrepreneurial Organization of Heterogeneous Capital” Journal of Management Studies 44 1165-1186

Finch J, Wagner B, Hynes N, 2010, "Trust and forms of capital in business-to-business activities and relationships" Industrial Marketing Management 39 1019-1027

Firkin P, 2003, "Entrepreneurial Capital", in Entrepreneurship: New Perspectives in a Global Age Eds A De Bruin, A Dupuis (Ashgate, Aldershot) pp 57-55

GOV.UK Press release, 2015, Michelle Mone OBE to lead government review on supporting business start-ups in disadvantaged communities available at: https://www.gov.uk/government/news/michelle-mone-obe-to-lead-government-reviewon-supporting-business-start-ups

Greene F J, Mole K F, Storey D J, 2008 Three decades of Enterprise Culture: Entrepreneurship, Economic Regeneration and Public Policy (Palgrave, London)

Greene F J, 2009, "Assessing the Impact of Policy Interventions: The Influence of Evaluation Methodology" Environment and Planning C 27 216-229

Greenman A, 2011, "Entrepreneurial activities and occupational boundary work during venture creation and developments in the cultural industries" International Small Business Journal 30 115-137

Grootaert C, Narayan D, Jones V N, Woolcock M, 2004, World Bank Working Paper No. 18 Measuring Social Capital An Integrated Questionnaire (World Bank, Washington, D.C.)

Guba E, Lincoln Y, 1989 Fourth Generation Evaluation (Sage, Thousand Oaks) 
Hannon P, 2003, "Exploring the Frontiers on Small Business" Environment and Planning C 21 1-2

Harrison E, Rose D, 2006, “The European Socio-economic Classification - ESeC User Guide”, available at: www.iser.essex.ac.uk/files/esec/guide/docs/UserGuide.pdf

Haber S, Reichel A, 2007, "The cumulative nature of the entrepreneurial process: the contribution of human capital, planning and environment resources to small venture performance" Journal of Business Venturing 22 119-45

Henry C, Hill F, Leitch C, 2003, "Developing a Coherent Enterprise Support Policy: A New Challenge for Governments" Environment and Planning C 21 3-19

Henry C, 2010, "SME Policy and the Role of Government" Environment and Planning C 28 191-194

House of Commons Cm 8980 2014, Our plan for growth: science and innovation available at:

https://www.gov.uk/government/uploads/system/uploads/attachment_data/file/387780/P U1719_HMT_Science_.pdf

House of Commons Cm 9039 2015, Government Support for Business - Eighth Report of Session 2014-15 available at:

https://www.gov.uk/government/uploads/system/uploads/attachment_data/file/420525/bi s-15-278-government-response-to-bis-committee-report-on-government-support-forbusiness.pdf

House of Commons Library 2015, Briefing Paper 7363 Policy on Small Firms 19972015 available at:

file://C:/Documents\%20and\%20Settings/login/My\%20Documents/Downloads/CBP$7363 \% 20(5) . p d f$

House of Commons Library 2015, Standard Note SN/EP/05878 New Enterprise Allowance available at:

file://C:/Documents\%20and\%20Settings/login/My\%20Documents/Downloads/SN0587 $8 \% 20(6) . p d f$

House of Commons Library 2015, Standard Note SN/EP/5651 Local Enterprise Partnerships available at:

http://www.parliament.uk/business/publications/research/briefingpapers/SN05651/local-enterprise-partnerships 
Huggins R, Williams N, 2009, "Enterprise and public policy: a review of Labour government intervention in the United Kingdom" Environment and Planning C: Government and Policy $2719-41$

Huggins R, Williams N, 2011, "Entrepreneurship and regional competitiveness: The role and progression of policy" Entrepreneurship and Regional Development 23 907-932

Jayawarna D, Rouse J, Crompton H, 2007, The NES Follow Up Survey 2006: An Evaluation of the Experiences of New Entrepreneur Scholars and their business Report prepared on behalf of the Learning and Skills Council

Jayawarna D, Jones O, MacPherson A, 2014, "Entrepreneurial potential: The role of human and cultural capitals" International Small Business Journal 32 918-943

Jones O, Jayawarna D, 2010, "Resourcing new businesses: social networks, bootstrapping and firm performance" Venture Capital 12 127-152

Karatas-Ozkan M, 2011, "Understanding relational qualities of entrepreneurial learning: Towards a multi-Layered approach” 23 877-906

Kalantaridis C, Bika Z, 2006, "Local embeddedness and rural entrepreneurship: casestudy evidence from Cumbria" Environment and Planning A 38 1561-1579

Kennedy P, 2004, "Making global society: friendship networks among transnational professionals in the building design industry" Global Networks 4 157-179

Keogh W, 2002, “Small Firm Policy” Environment and Planning C 20 159-161

Kim P H, Aldrich H E, Keister L A, 2006, “Access (Not) Denied: The Impact of Financial, Human, and Cultural Capital on Entrepreneurial Entry in the United States" Small Business Economics 27 5-22

Kitching J, 2006, "Can Small Businesses Help Reduce Employment Exclusion" Environment and Planning C 24 869-884

Klyver K, Foley D, 2012, "Networking and culture in entrepreneurship" Entrepreneurship and Regional Development 24 561-588

Kothari S, Handscombe R, 2007, "Sweep or seep? Structure, culture, enterprise and universities" Management Decision 45 43-61

Kwon S, Adler P, 2014, "Social Capital: Maturation of a Field of Research" Academy of Management Review 39 412-422 
Law A, Mooney G, 2012, "Competitive nationalism: state, class, and the forms of capital in devolved Scotland" Environment and Planning C: Government and Policy 30 62-77

Lazear E, 2005, “Entrepreneurship” Journal of Labor Economics 23 649-680

Lechman D, Schnabel C, 2014, “Are the self-employed really jacks-of-all-trades? Testing the assumptions and implications of Lazear's theory of entrepreneurship with German data" Small Business Economics 42 59-76

Learning and Skills Council 2007, Evaluation of the New Entrepreneurship

Scholarships available at: http://fskills-

test.idoxgroup.com/sds/search/download.do;jsessionid=7D38549087F3AAFBA9A4BF5 7A5FBF86E?ref $=$ B7407

Lee D, 2011, "Networks, cultural capital and creative labour in the British independent television industry" Media Culture \& Society 33 549-565

Lee N, Cowling M, 2015, "Do Rural Firms Perceive Different Problems? Geography, Sorting, and Barriers to Growth in SMEs" Environment and Planning C 33 25-42

Lee R, Jones O, 2008, "Networks, Communication, and Learning during Business Startup: The Creation of Cognitive Social Capital” International Small Business Journal, 26 559-594

Lee R, Tuselmann H, Jayawarna D, Rouse J, 2011, "Investigating the social capital and resource acquisition of entrepreneurs residing in deprived areas of England" Environment and Planning C 29 1054-1072

Leitch C, McMullan C, Harrison T, 2013, "The Development of Entrepreneurial Leadership: The Role of Human, Social and Institutional Capital" British Journal of Management 24 347-366

Light I, Dana L P, 2013, "Boundaries of Social Capital in Entrepreneurship" Entrepreneurship Theory and Practice 37 603-624

Lin, N. (1999b) Building a Network Theory of Social Capital. Connections, 22, 28-51

Lord Young Feb 2015, Report on Small Firms 2010-2015 available at: https://www.gov.uk/government/publications/report-on-small-firms-2010-to-2015-bylord-young

Lyon F, Sepulveda L, Syrett S, 2007, "Enterprising Refugees: Contributions and Challenges in Deprived Urban Areas" Local Economy 22 362-375 
Marlow S, Carter S, Shaw E, 2008, "Constructing Female Entrepreneurship Policy in the UK: Is the US a Relevant Benchmark?” Environment and Planning C 26 335-351

Martinez M A, Aldrich HE, 2011, "Networking strategies for entrepreneurs: balancing cohesion and diversity" International Journal of Entrepreneurial Behaviour and Research 17 1355-2554

Mason C, 2009, "Policy as a Focus for Small Business Research" Environment and Planning C 27 191-194

Mason C, Brown R, 2013, "Creating good public policy to support high-growth firms" Small Business Economics 40 211-225

Monsen E, Mahagaonkar P, Dienes C, 2012, "Entrepreneurship in India: the question of occupational transition" Small Business Economics 39 359-382

Mosey S, Wright M, 2007, "From Human Capital to Social Capital: A Longitudinal Study of Technology-Based Academic Entrepreneurs" Entrepreneurship, Theory and Practice 31 909-935

Murphy L, Huggins R, Thompson P, 2015, "Social capital and innovation: A comparative analysis of regional policies" Environment and Planning $C$ DOI: $10.1177 / 0263774 X 15597448$

Nahapiet J, Ghoshal S, 1998, "Social capital, Intellectual Capital, and the Organizational Advantage" Academy of Management Review 23 242-266

Nesta 2011, Vital growth - The importance of high-growth businesses to the recovery available at: https://www.nesta.org.uk/sites/default/files/vital_growth.pdf

Nowicka M, 2013, "Positioning Strategies of Polish Entrepreneurs in Germany: Transnationalizing Bourdieu's Notion of Capital” International Sociology 28 29-47

Obschonka M, Silbereisen R, Schmitt-Rodermund E, Stuetzer M, 2011, "Nascent entrepreneurship and the developing individual: Early entrepreneurial competence in adolescence and venture creation success during the career" Journal of Vocational Behavior 79 121-133

O'Cass A, Sok P, 2013, “The role of intellectual resources, product innovation capability, reputational resources and marketing capability combinations in firm growth" Environment and Planning C 32 996-1018 
Organisation for Economic Co-operation and Development OECD, 2014, SecretaryGeneral's Report to Ministers available at: http://www.oecd.org/about/secretarygeneral/SG-Annual-Report-to-Ministers-2014.pdf

Office of the Deputy Prime Minister ODPM, 2004, The Social Exclusion Unit available at:

http://webarchive.nationalarchives.gov.uk/+/http:/www.cabinetoffice.gov.uk/media/cabi netoffice/social_exclusion_task_force/assets/publications_1997_to_2006/seu_leaflet.pdf

Pickernell D, Packham G, Jones P, Miller C, Thomas B, 2011, “Graduate entrepreneurs are different: they access more resources?" International Journal of Entrepreneurial Behaviour and Research 17 183-202

Pickernell D, Atkinson C, Miller C, 2015, “Government SME intervention policy: perception is 9/10ths of the truth?" Environment and Planning $C$ 33 4-8

PRO INNO EUROPE 2008, Policies in support of high growth SMEs - Thematic

Report available at:

proinno.europe.eu/sites/default/files/page/10/07/Thematic_Report_July_2008_-

_High_Growth_SMEs.pdf

Putnam R D, 2000 Bowling alone (Simon \& Schuster, New York)

Ram M, Smallbone D, 2002, "Ethnic Minority Business Policy in the Era of the Small Business Service" Environment and Planning C 20 235-249

Ram M, Jones T, 2008, "Ethnic-Minority Businesses in the UK: A Review of Research and Policy Developments" Environment and Planning C 26 352-374

Ram M, Theodorakopoulos N, Jones T, 2008, "Forms of capital, mixed embeddedness and Somali enterprise" Work, Employment and Society 22 427-446

Ram M, Trehan K, Rouse J, Woldesenbet K, Jones T, 2012, "Ethnic Minority Business Support in the West Midlands: Challenges and Developments" Environment and Planning C 30 504-519

Ritchie B, 2006, “Small Business Policy” Environment and Planning C 24 795-798

Robson M, Wijbenga F, Parker S C, 2009, "Entrepreneurship and Policy - Challenges and Directions for Future Research" International Small Business Journal 27 531-535

Rouse J, Jayawarna D, 2006, "The financing of disadvantaged entrepreneurs - Are enterprise programmes overcoming the finance gap?" International Journal of Entrepreneurial Behaviour and Research 12 388-400 
Rouse J, Kitching J, 2006, "Do Enterprise Support Programmes Leave Women Holding the Baby?" Environment and Planning C 24 5-19

Rouse J, Jayawarna D, 2011, "Structures of Exclusion from Enterprise Finance" Environment and Planning C 29 659-676

Samuelsson M, Davidsson P, 2009, "Does venture opportunity variation matter? Investigating systematic process differences between innovative and imitative new ventures" Small Business Economics 33 229-255

Schumpeter J A, 1934 The Theory of Economic Development (Harvard University Press, Cambridge MA)

Scott M, 2012, "Cultural entrepreneurs, cultural entrepreneurship: Music producers mobilising and converting Bourdieu's alternative capitals" Poetics 40 237-255

Shane S, 2009, "Why encouraging more people to become entrepreneurs is bad public policy” Small Business Economics 33 141-149

Shaw E, Lam W, Carter S, 2008, "The role of entrepreneurial capital in building service reputation” Service Industries Journal 28 899-917

Shaw E, Marlow S, Lam W, Carter Sara L, 2009, "Gender and entrepreneurial capital: implications for firm performance" International Journal of Gender and Entrepreneurship $125-41$

Shaw E, Gordon J, Harvey C, MacLean M, 2013, "Exploring contemporary entrepreneurial philanthropy" International Small Business Journal 31 580-599

Slack J, 2005, "The New Entrepreneur Scholarships: self-employment as a means to tackle social deprivation" Education and Training 47 447-455

Smallbone D, Baldock R, North D, 2003, "Policy Support for Small Firms in Rural Areas: The English Experience" Environment and Planning C 21 825-841

Smith V, 2010, "Enhancing employability: Human, cultural, and social capital in an era of turbulent unpredictability" Human Relations 279-303

Spigel B, 2013, "Bourdieuian approaches to the geography of entrepreneurial cultures" Entrepreneurship and Regional Development 25 804-818 
SQW Economic Development Consultants, 2005, Interim Evaluation of Knowledge transfer programmes funded by the Office of Science and Technology through the science budget available at: www.sqw.co.uk/file_download/40

Stam W, Arzlanian S, Elfring T, 2014, "Social capital of entrepreneurs and small firm performance: A meta-analysis of contextual and methodological moderators" Journal of Business Venturing 29 152-173

Storey D, Greene F, 2010 Small Business and Entrepreneurship (Pearson, Harlow)

Stringfellow L, MacLean M, 2014, "Space of Possibles"? Legitimacy, Industry Maturity, and Organizational Foresight" Strategic Change 23 171-183

Sutherland L, Burton R, 2011, "Good Farmers, Good Neighbours? The Role of Cultural Capital in Social Capital Development in a Scottish Farming Community" Sociologia Ruralis 51 238-255

Svendsen G L, Sorensen, J F, 2007, “There's more to the picture than meets the eye: Measuring tangible and intangible capital in two marginal communities in rural Denmark" Journal of Rural Studies 23 453-471

Tatli A, Ozbilgin F, 2012, "An Emic Approach to Intersectional Study of Diversity at Work: A Bourdieuan Framing” International Journal of Management Reviews 14 180200

Tatli A, Vassilopoulou J, Ozbilgin M, Forson C, Slutskaya N, 2014, “A Bourdieuan Relational Perspective for Entrepreneurship Research" Journal of Small Business Management 52 615-632

Taylor D W, Jones O, Boles K, 2004, "Building social capital through action learning: an insight into the entrepreneur" Education and Training 46 226-235

Taylor M, Plummer P, 2003, "Promoting local economic growth: the role of entrepreneurship and human capital" Education and Training 45 558-563

UK Commission for Employment and Skills UKCES, 2011, Skills for self-employmentEvidence Report 31 available at: www.ukces.org.uk/publications/er31-skills-foremployment

Vershinina N, Barrett R, Meyer M, 2011, "Forms of capital, intra-ethnic variation and Polish entrepreneurs in Leicester" Work Employment and Society 25 101-117

Watson T J, 2008 Sociology, Work and Industry Fifth Edition (Routledge, Oxon) 
Westlund H, Bolton R, 2003, "Local Social Capital and Entrepreneurship", Small Business Economics 21 77-113

White Paper 2010, Local growth: realising every place's potential Presented to Parliament by the Secretary of State for Business, Innovation and Skills by Command of Her Majesty, available at:www.bis.gov.uk/assets/BISCore/economicdevelopment/docs/L/cm7961-local-growth-white-paper.pdf

Williams N, 2013, "Entrepreneurship and the role of policy", Environment and Planning C: Government and Policy 31 1-4

Williams N, Williams C C, 2011, “Tackling barriers to entrepreneurship in a deprived urban neighbourhood", Local Economy 26 30-42

Williams N, Huggins R, 2013, "Supporting entrepreneurship in deprived communities: a vision too far?" Journal of Small Business and Enterprise Development 20 165-180

Wilson L, Whittam G, Deakins D, 2004, “Women's Enterprise: A Critical Examination of National Policies" Environment and Planning C 22 799-815

Wright M, Stigliani I, 2013, "Entrepreneurship and growth" International Small Business Journal" 31 3-22

Wright M, Roper S, Hart M, Carter S, 2015, "Joining the dots: Building the evidence base for SME growth policy” International Small Business Journal 33 3-11

Woolcock M, Narayan D, 2000, "Social Capital: Implications for Development Theory, Research, and Policy" The World Bank Research Observer 15 225-249

Work Foundation 2012, The private sector, Local Enterprise Partnerships and growth available at:

http://www.theworkfoundation.com/DownloadPublication/Report/324 The\%20Busines s\%20of\%20Cities\%20FINAL.pd

Zahra S, Wright M, 2011, "Entrepreneurship's Next Act" Academy of Management Perspectives 25 67-83

Table 1 Respondents and ESec classification 


\section{Respondent Education Business Description- (ISCO88 code) ESeC Activities}

\begin{tabular}{|c|c|c|c|}
\hline SEC - Ian, & BSc Degree, A & Software development and & $(200,213)$ \\
\hline Male & Levels, GCSEs & web design in healthcare & $\begin{array}{l}\text { Professional and } \\
\text { higher technician }\end{array}$ \\
\hline $\begin{array}{l}\text { SEC - Mo, } \\
\text { Male }\end{array}$ & $\begin{array}{l}\text { BSc Degree, A } \\
\text { Levels, GCSEs }\end{array}$ & $\begin{array}{l}\text { Software development, web } \\
\text { design and call centre }\end{array}$ & $(200,213)$ \\
\hline $\begin{array}{l}\text { SEC - Jon, } \\
\text { Male }\end{array}$ & $\begin{array}{l}\text { BSc Degree, } \\
\text { B-Tech, }\end{array}$ & $\begin{array}{l}\text { operations } \\
\text { Web design and application }\end{array}$ & $\begin{array}{l}\text { Professional and } \\
\text { higher technician }\end{array}$ \\
\hline $\begin{array}{l}\text { SEC - } \\
\text { Zainfur, } \\
\text { Male }\end{array}$ & $\begin{array}{l}\text { BSc Degree, A } \\
\text { Levels, GCSEs }\end{array}$ & $\begin{array}{l}\text { of multimedia solutions in } \\
\text { fashion } \\
\text { Software development, web }\end{array}$ & $\begin{array}{l}(200,213) \\
\text { Professional and } \\
\text { higher technician }\end{array}$ \\
\hline $\begin{array}{l}\text { SEC - } \\
\text { Zobair, }\end{array}$ & $\begin{array}{l}\text { BSc Degree, A } \\
\text { Levels, GCSEs }\end{array}$ & $\begin{array}{l}\text { design, web hosting and } \\
\text { wireless technology }\end{array}$ & $\begin{array}{l}(200,213) \\
\text { Professional and }\end{array}$ \\
\hline Male & BSc Degree, A & $\begin{array}{l}\text { Software development and } \\
\text { Bluetooth/electronic }\end{array}$ & ) \\
\hline $\begin{array}{l}\text { SEC - Sunit, } \\
\text { Male }\end{array}$ & Levels, GCSEs & taggi & $\begin{array}{l}\text { Professional and } \\
\text { higher technician }\end{array}$ \\
\hline SEC - Dan, & $\begin{array}{l}\text { BA Degree, A } \\
\text { Levels, GCSEs }\end{array}$ & $\begin{array}{l}\text { IT consultancy, specialist } \\
\text { web design and software }\end{array}$ & 200, 213) \\
\hline & BA Degree, A & development & Professional and \\
\hline $\begin{array}{l}\text { SEC - } \\
\text { Jason, }\end{array}$ & $\begin{array}{l}\text { Levels, } \\
\text { GNVQs }\end{array}$ & $\begin{array}{l}\text { Sustainable environment } \\
\text { consultant and specialist }\end{array}$ & $\begin{array}{l}\text { higher technician } \\
(200,241)\end{array}$ \\
\hline & $\mathrm{MA}, \mathrm{BA}$ & designer of packaging & Professional and \\
\hline $\begin{array}{l}\text { SEC - } \\
\text { Georgina, }\end{array}$ & $\begin{array}{l}\text { Degree, } \quad \text { A } \\
\text { Levels, GCSEs }\end{array}$ & $\begin{array}{l}\text { Sustainable environment } \\
\text { consultant and specialist }\end{array}$ & $\begin{array}{l}\text { higher technici } \\
(200,241)\end{array}$ \\
\hline & BA Degree, A & designer of $\mathrm{f}$ & Professional and \\
\hline SEC - & Levels, GCSEs & Metalwork & higher tech \\
\hline Female & & designer/sculptor and & $(200,245)$ \\
\hline $\mathrm{ES}-$ & & prototyper & higher technician \\
\hline $\begin{array}{l}\text { Simon, } \\
\text { Male }\end{array}$ & . & & \\
\hline
\end{tabular}




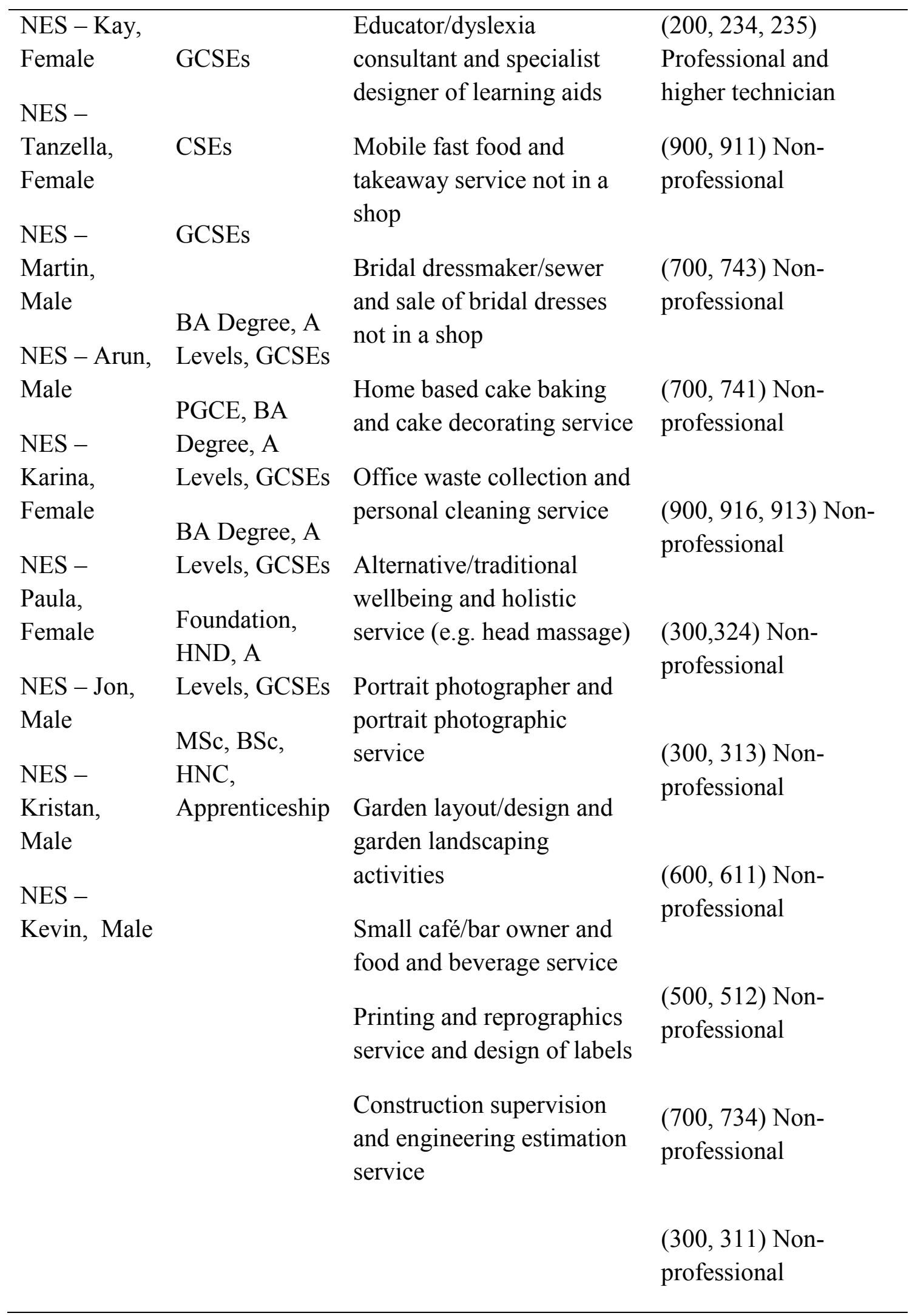


Table 2 Summary of entrepreneurship, occupation and intangible capitals

Professional and higher technician
Non professional

'Affiliations' with generic products, goods and materials.

'Embodied' dispositions for survivability and low scalability.

Primarily 'bonding' network engagement for 'getting by'.

'Evaluative judgement' for affective and personal routines, and less formal businesses.

Note: There was a within difference regarding embodied dispositions in the nonprofessional sample. Non-professional respondents not educated to degree level prioritised survivability, but non-professional respondents educated to degree level prioritised survivability with some cautious growth aspirations. 
Figure 1 Core codes and associated categories

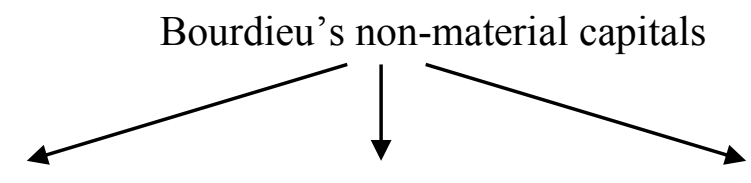

Core

codes

Cultural

Social

Symbolic
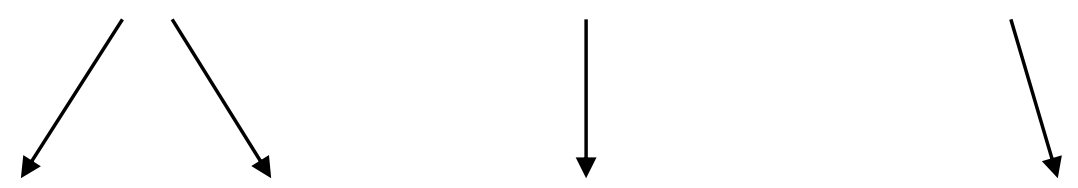

$\begin{aligned} & \text { Associated } \\ & \text { categories }\end{aligned}$
$\begin{aligned} & \text { 'Objectified 'Embodied 'Network Structure' 'Reputation' being } \\ & \text { cognizant of others products, goods about life and ties }\end{aligned}$
assessments
materials work 
